University of Louisville

ThinkIR: The University of Louisville's Institutional Repository

Electronic Theses and Dissertations

1942

\title{
Tuberculosis in Louisville and Jefferson County.
}

Anna J. Haines

University of Louisville

Follow this and additional works at: https://ir.library.louisville.edu/etd

Part of the Political Science Commons

\section{Recommended Citation}

Haines, Anna J., "Tuberculosis in Louisville and Jefferson County." (1942). Electronic Theses and Dissertations. Paper 1975.

https://doi.org/10.18297/etd/1975

This Master's Thesis is brought to you for free and open access by ThinkIR: The University of Louisville's Institutional Repository. It has been accepted for inclusion in Electronic Theses and Dissertations by an authorized administrator of ThinkIR: The University of Louisville's Institutional Repository. This title appears here courtesy of the author, who has retained all other copyrights. For more information, please contact thinkir@louisville.edu. 
UNIVERSITY OF LOUISVILUE

TUBERCULOSIS IN LOUISVILIE IND JEFTERSON COUNTY

\author{
A Dissertation \\ Submitted to the Faculty \\ Of the Graduate School of the University of Louisville \\ In Fartial Fulfillment of the \\ Requirements for the Degree \\ of haster of Arts
}

Departnent of Political science

By

Anna J. Haines

Year

1942 


\section{UHE UNWvessir LIBRARIES}

This PDF document is a scanned copy of a paper manuscript housed in the University of Louisville (UofL) Libraries. The quality of this reproduction is greatly dependent upon the condition of the original paper copy. Indistinct print and poor quality illustrations are a direct reflection of the quality of materials that are available for scanning. The UofL Libraries greatly appreciates any better copies that can be made available for replacement scans. 


\author{
NAME OF STUDENT: Anna J. Haines \\ TITLE OF THESIS: "Tuberculosis in Louisville \\ and Jefferson County"
}

APPROVED BY READING COMMITTEE COMPOSED OF THE FOLLOWING MEMBERS :

John J. Cronin

James Morgan Read

Robert I. Kutak

NAME OF DIRECTOR:

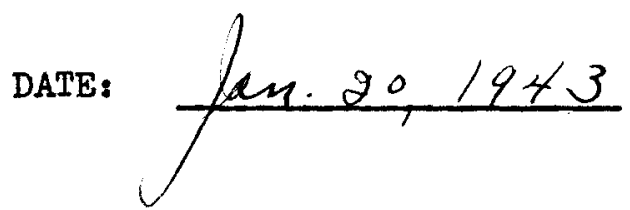




\section{Table of Contents}

I. Introduction

$$
\begin{aligned}
& \text { p. } 1-3 \\
& \text { p. } 4-7
\end{aligned}
$$

II. General Extent of Tuberculosis in Louisville and Jefferson County

III. Extent of Tuberculosis Among Special Groups and Areas

$$
\begin{array}{ll}
\text { A. According to hace } & \text { p. } 8 \\
\text { B. According to Sex } & \text { p. } 9 \\
\text { C. According to Sex and Race } & \text { p. } 9-11 \\
\text { D. According to Age Groups } & \text { p. } 12-17 \\
\text { E. Accoraing to Geographic Area } & \text { p. } 18-23 \\
\text { F. According to Occupation } & \text { p. } 23-26 \\
\text { G. According to Larital Status } & \text { p. } 26-30 \\
\text { H. Accoràing to Place of Death } & \text { p. } 30-32 \\
\text { I. Comaunity Agencies and Tuberculosis } & \text { p. } 32-39
\end{array}
$$

IV. Agencies Responsible for Tuberculosis and Their Cost

$$
\begin{aligned}
& \text { p. } 40-43 \\
& \text { p. } 44-46 \\
& \text { p. } 47-49 \\
& \text { p. } 50-62 \\
& \text { p. } 63-64
\end{aligned}
$$

VII. Suggestions for More Effective Control of Tuberculosis

VIII. Conclusion 
I. Introduction 
TUBERCULOSIS IN LOUISVILLE AND JEFFLRSON COUNTY

\section{Introduction}

There is an easy complacency in Louisville about tuberculosis. Some years ago the city and Jefferson County jointly built a beautiful and spacious sanatorium at Waverley Hills. Visiting physicians praise its adequate equipment and staff. Hospital statistics prove that it supplies the city and county with more than the standard number of beds for tuberculous patients; its provision for Negro patients is unusually generous. These pleasing truths tend to dull anxiety over tuberculosis as a local menace. other social and health problems may be admitted, but it is not generally considered that tuberculosis presents any difficulties.

To what extent is this satisfaction justified? Is tuberculosis no longer an important health problem? Do Louisville and Jefferson County compare favorably with other parts of the country in this respect? What is the financial cost of the disease to the comaunity? Is expenditure of tax money and private contributions for tuberculosis control resulting in decreased incidence?

Since there are no generally available answers to these questions the following study of tuberculosis in Louisville and Jefferson County was undertaken. It is essentially a study of the social and economic factors connected with tuberculosis and makes no attempt to approach the medical aspects of the disease.

Tuberculosis was found to present very different problems when studied in detail than when seen as a whole. Particularly was this true in regard to its incidence among white and Negro peoples. Other 
classifications showing variations were those involving sex, age, marital condition, geographic distribution, occupation, economic status and institutional residence. An inquiry into all of these factors, as they apply to the tuberculous, forms one section of this $r$ port. Other sections are devoted to the facilities for the care and prevention of tuberculosis in Louisville and Jefferson County, to the cost in terms of taxation and contributions by private agencies working in this field, and to the problem of tuberculosis among non-residents.

As the local tuberculosis statistics for any one year may show a-typical variations and as trends are of especial value in health studies, it was decided to collect and analyze the statistics of a five year period. The most recent available local figures were those from 1934 to 1938 inclusive, but national figures desireable for comparison could be obtained in detailed breakdown only for the census years. Although some of the 1940 Census data were issued before the final draft of this study was finished, other required national data were not yet ready nor had any reports been published by national tuberculosis agencies based on the 1940 Census material. Therefore the basic data used in this study were the United States Census figures for 1930 and the local death certificates giving tuberculosis as the cause of demise during the five years 1934 to 1938.

All original death certificates for Louisville and Jefferson County are preserved in the vaults of the state Department of liealth, but copies of those indicating tuberculosis as the cause of death are sent to the Louisville Tuberculosis Association. Local tuberculosis figures and 
rates in the statistical tables of the report are based on these official copies made by employees of the State Health Departwent. Feferences to other original sources are credited in the footnotes.

A survey of tuberculosis based on active cases as well as on deaths might seem to have more significance, especially in computing the cost of the disease to the community. It is, however, impossible to obtain data on all current cases; private physicians are unwilling to furnish information which concerns their patients; death certificates are the first public record of many cases, although officially tuberculosis is a reportable disease. Authorities in this field, however, believe that there is a direct relation between the number of tuberculosis deaths and the incidence of the disease in a comunity, and that the findings which relate to the deceased are true for the entire number of cases involved.

1. Iiscock, Ira V., Community Health Organization, p. 99 
II. General Extent of Tuberculosis in Louisville and Jefferson County 
II. General Extent of Tuterculosis in Louisville and Jefferson County

The 1930 U.S. Census gives the total population for Lolisville and Jefferson County as 355,350 , of whom 304,382 were white and 51,168 were Negro. Local rates throughout this report are based on these population figures.

During the period from January 1, 1934 through December 31, 1938 there were 1378 deaths from tuberculosis in Louisville and Jefferson County. Of these, 145 vere deaths of persons whose residence was outside of the city and county. Since the original source of infection of this group is beyond local control and since the group presents other features peculiar to itself, the problems of the non-resident will be considered in a later section of the report. For the years included in the study it was impossible to obtain the number of deaths of residents of the city and county who died outside of that area.

The 1233 persons, therefore, who were residents of Louisville and Jefferson County and who died there from tuberculosis in the years 1934 to 1938 inclusive, are the primary subject of this study. The following table gives the number of deaths and the deathrates for each year, as well as the annual average for the entire period. Because only legal residents who died locally are being considered the rates are slightly lower than those found in the official reports. While the local rate fell during these five years from 78.2 to 66.7 per 100,000 population, the annual deathrate from tuberculosis in the entire state of Kentucky fell from 74.7 to 66.1 , and in the United States as a whole from 56.1 to 48.6 per 100,000 population. 


\section{TABLI I}

Tuberculosis Deaths and Deathrates, Louisville and Jefferson County $1934-1938$

\begin{tabular}{lcc}
\hline Year & Number Deaths & $\begin{array}{c}\text { Rate per } \\
100,000 \text { Pop. }\end{array}$ \\
\cline { 2 - 3 } 1934 & 279 & 78.2 \\
1935 & 209 & 58.8 \\
1936 & 233 & 65.5 \\
1937 & 275 & 77.3 \\
1938 & 237 & 66.7 \\
Total & 1233 & - \\
Annual Average & 247 & 69.3 \\
\hline
\end{tabular}

From this uneven succession of figures no very definite trend can be established, although figures for the later years are never as high as for the first; in view of the fact that the population during the later years was certainly somewhat higher than during the early years, although the 1930 Census population was consistently used as a divisor in finding rates it is probable that there may have been a greater decline than is apparent.

When compared with other cities within its population class Louisville, exclusive of Jefferson County, shows a high tuberculosis death rate. of the 237 deaths registered for both city and county in 1938 there were 218 reported to the New York Tuberculosis and liealth Association from the city itself, giving a local city deathrate in that year of 71 per 100,000 population. In the same year the local resident tuberculosis death rates of the thirteen other cities in the United States with populations from 300,000 to 400,000 ranged from 20 to 99 . only two, Houston with 78 
1

and itlanta with 99, were higher than Louisville. It may be noted, however, that most of these cities were in the northern part of the United States where both climate and small proportion of Negro citizens contributed to a lower deathrate.

In the most recent (1939) edition of Comunity Health organization, Dr. Hiscock states that

- It is customary to estimate that there should be five known cases (diagnosed as active tuberculosis) under supervision for each annual death, on the average. With the present size of family there are at least three contacts of each active case. It may thercfore be figured that the tuberculosis problems of a community concern roughly 24 people for each annual death, i.e., the fatal case, (its) three contacts, five (other) active cases, and fifteen contacts of these cases." z

On the basis of these figures Louisville and Jefferson County would have each year, in addition to 247 deaths from tuberculosis, 1235 active cases of the disease and 4446 persons who were contacts. These 5928 persons annually in need of medical examinations and supervision represnt almost $2 \%$ of the combined population of the city and county. The medical, social and financial problems presented by such a group make no small demands on total community resources. In order to appreciate what these demands are it is necessary to ascertain the prevalence of the disease among various age groups, racial groups, geographic areas and social and economic strata. "Unless we appreciate the effect of age, sex,

1. New York Tuberculosis and Health Association, Tuberculosis Wiortality In Forty-six Large Cities of the United States During the Year 1938, p.I

2. Hiscock, Ira V., op.cit., p.100 
race and nationality, marital status, occupation and the other factors which influence vital phenomena, we may encounter the fallacy of concealed classification in our interpretation of vital facts. The most serious error comes in the interpretation of rates based on unlike age groupings." Results of inquiry into these fields are presented in the following paragraphs.

1. Hall, H.F., Public Health Statistics, p. 81 
III. Extent of Tuberculosis Among Special Groups and Areas

A. According to Race

B. According to sex

C. According to Sex and Race

D. According to sige Groups

E. According to Geographic Area

F. According to occupation

G. According to Harital Status

H. According to Flace of Death

I. Comunity Agencies and Tuberculosis 
III. Extent of Tuberculosis Among Special Groups and Areas

A. Tuberculosis According to Race

Tuberculosis has long been accepted as an especially serious threat to Negroes, a fact substantiated by local figures. Although they make up only $14.3 \%$ of the local population, $37.5 \%$ of local deaths from tuberculosis were among Negroes, as is shown ib the folloving table.

\section{TABLE II}

Deaths from Tuberculosis According to Face Louisville and Jefferson County Residents, 1934-1938

\begin{tabular}{lccc} 
& White & Negro & Total \\
Population & 304,382 & 51,168 & 355,350 \\
Percent of total population & $85.7 \%$ & $14.3 \%$ & - \\
Deaths & 770 & 463 & 1233 \\
Percent of total deaths & $62.5 \%$ & $37.5 \%$ & - \\
\hline
\end{tabular}

These proportions are not very different from those obtaining in the country as a whole where Negroes, who wake up approximately $10 \%$ of of the population supply $25 \%$ of the deaths from tuberculosis. Almost everywhere the Negro deathrate is from three to five times higher than the white rate. The local average annual deathrates were 40.6 for the white and 180.5 for the Negro population, or a ratio of 1 to 4 . These general figures, however, mask the more silnificant and spotty spread of rates which is revealed in the breakdown by age and sex, as well as race.

1. Erolet, Godias J., Epidemology of Tuberculosis, Journal of Preventive liedicine, larch, 1930 
B. Tuberculosis According to Sex

of the 1233 total deaths there were 700 males and 533 females, or a ratio of 56 males to 43 females. In the general population of Louisville and Jefferson County there is a ratio of 49 males to 51 females. A comparison of these ratios indicates special hazards for men in connection with infection and death from tuberculosis. This deduction is corroborated by the Local and national tuberculosis deathrates which are, for Louisville and Jefferson County 81.1 for males and 58.5 for females, and for the nation as a whole in $1930,77.0$ for males and 58.2 for females.

It is a curiuos and unexplained fact that "The tuberculosis deathrate for males is higher than that for females in England and Wales, Australia, Austria, Belgium and Scotland, but in the Netherlands, Sweden, Switzerland and Japan it is usual for the fenale tuberculosis rate to be higher than the male."

C. Tuberculosis According to $S \in x$ and Race Breaking the figures down along racial as well as sex lines, it appears that these hazards are not equally distributed between white and Negromen. While there is the same ratio between men and women in both the white and colored races, i.e., 49 men to 51 women, there is a ratio

1. National Tuberculosis Association, New and Supplementary Facts and Figures sbout Tuberculosis, p. 10

2. National Tuberculosis Association, Facts and Figures About Tuberculosis, p. 10 
among those dying from tuberculosis of 53 white males to 47 white females, compared to a ratio of 64 Negro males to 36 Negro females. The following table gives the figures on which these ratios are based.

TABLE III

Deaths From Tuberculosis by Sex Louisville and Jefferson County Resicients, 1934-38

\begin{tabular}{|c|c|c|c|c|c|c|c|c|}
\hline & \multicolumn{3}{|c|}{ White } & \multicolumn{3}{|c|}{ Negro } & \multirow{2}{*}{$\begin{array}{l}\text { Total } \\
\text { wale }\end{array}$} & \multirow{2}{*}{$\begin{array}{l}\text { Total } \\
\text { Female }\end{array}$} \\
\hline & hale & Female & Total & Eale & Female & Total & & \\
\hline Five Year Total & 406 & 364 & 770 & 294 & 169 & 463 & 700 & 533 \\
\hline Annual Average & 81 & 73 & 154 & 59 & 34 & 93 & 140 & 107 \\
\hline
\end{tabular}

Although the general statement that locally more men than women die from tukerculosis is true for both races, the difference in favor of the Negro female is marked. This difference holds consistently for Negroes in each separate year of the study, while among whites there was one year when more females died than males. In one age group, however, the general statement does not hold; among young white aciults from 15 to 24 years of age there are more than twice as many deaths of females as of males. Curiously this variation is not true for Louisville Negroes, although in other parts of the country the excess of female over male deaths at this age is outstanding in both races.

Many explanations have been made for the generally recognized fact of the greater susceptability of young women to tuberculosis, but none has been fully accepted by the medical profession; nor has any theory been advanced as to the cause for the unusual freedom from tuberculosis enjoyed by the young Negro women of Louisville and Jefferson County. 
In the following table the average annual deathrates from tuberculosis for Lou svilie and Jefferson County in the years 1934 to 1938, broken down by sex and race are compared vith corresponding rates for the United States as a whole in the year 1930, the most recent yeur for which similar national data are uvailable.

\section{TABLE IV}

National and Local Tuberculosis Deathrates per 100,000 Population

Louisville and

$\frac{\text { White }}{\text { Wale Fernale Total }}$

$\frac{\text { Negro }}{\text { Wiale Female Total }}$

Jefiterson County Annual Average 1934-1938

$$
\begin{array}{llllll}
55.0 & 46.5 & 40.6 & 233.4 & 127.0 & 180.5
\end{array}
$$

United States

1930

$$
\begin{array}{llllll}
64.9 & 52.3 & 57.9 & 199.3 & 190.2 & 183.6
\end{array}
$$

According to these figures the local rates compare favorably with the national in ali the items except the Negro male and the total male population. This last figure would seen to be atetermined entirely by the excessively high rate for Negro males since the local white male rate is lower than the national male rate. The unusually small number of deaths among Negro women brings the local general Negro rate close to the national Negro rate. Only a detailed breakdown of the statistics reveals the real nature of the problem confronting local public he lth workers, namely, the abnornally high number of deaths among local Negro men.

1. National Tuberculosis Association, Nev and Supplementary Facts and Figures About Tuberculosis, p. 16 incorrect, but is so given.) 
D. Tuberculosis According to ige Groups

The factors of race and sex are so inextricably associated with the factor of age in connection with tuberculosis that they are considered jointly in the following paragraphs. In studying deaths from tuberculosis by age group there are two lines of inquiry which must be kept separate; first, within what age groups are there the most deaths? and second, within what age groups is the rate of death the highest, taking into consideration the total population for that age group? The age groupings recommended by the American Public Health Association as practical for such studies are as follows:

$\begin{array}{ll}\text { Birth through four years } & \text { - the preschool group } \\ \text { Five through fourteen years } & \text { - school age group } \\ \text { Fifteen through twenty-four years } & \text { - young adult group } \\ \text { Twenty-five through forty-four years } & \text { - active work group } \\ \text { Forty-five through sixty-four years } & \text { - midle age group } \\ \text { Sixty-five years and over } & \text { - old age group } \\ \text { Age Unknown } & - \text { a small group }\end{array}$

However, the number of local individuals dying in the age group from birth through four years and from five through fourteen years was so small that it seemed statistically more sound to combine these two into one "childhood age group", including all those under fifteen years of age. In computing rates the insignificant local "age unknown" group was omitted.

Table $V$ presents the total number of resident deaths from tuberculosis in Louisville and Jefferson County in the five year period 1934-1938, according to age, sex and race. 
TABLE V

Total Deaths from Tuberculosis by Age, Sex and Face, 1934-1938 Louisville and Jefferson County Fesidents

\begin{tabular}{|c|c|c|c|c|c|c|c|}
\hline \multirow[b]{2}{*}{ Age Group } & \multicolumn{3}{|c|}{ White } & \multicolumn{3}{|c|}{ Negro } & \multirow{2}{*}{$\begin{array}{l}\text { Grand } \\
\text { Total }\end{array}$} \\
\hline & hale & Female & Total & hale & Female & Total & \\
\hline Birth through 14 years & 26 & 21 & 47 & 8 & 12 & 20 & 67 \\
\hline 15 through 24 years & 22 & 51 & 73 & 45 & 46 & 91 & 164 \\
\hline 25 through 44 years & 165 & 145 & 310 & 121 & 78 & 199 & 509 \\
\hline 45 through 64 years & 134 & 95 & 229 & 106 & 21 & 127 & 356 \\
\hline 65 years and over & 57 & 50 & 107 & 9 & 7 & 16 & 123 \\
\hline Age Unknown & 2 & 2 & 4 & 5 & 5 & 10 & 14 \\
\hline Total & 406 & 364 & 770 & 294 & 169 & 463 & 1233 \\
\hline
\end{tabular}

The figures in this table show that the largest number of local victims of tuberculosis are men and women within the twenty-five to fortyfour year span, whether we consider the totals or the individual columns of White male and female or of Negro male and female. This fact is of particular importance because of the lost economic value of these men and women stricken down in the prime of life. Host old people and children are not self-supporting; their relatives or public funds mast ke responsible for their support. The difference in cost of their upkeep, sick or well, is in degree only. Tuberculosis, however, takes its highest toll from the ranks of those who are normally not only self-supporting, but who support others beside themselves. The cost to the comranity of their illness does not end with the care given to them individually.

Do Louisville and Jefferson County have a disproportionate number of tuberculosis deaths in the young adult and active working age group? A comparison between the percentage of deaths in the various age groups and the percentage of people in the total population in those age groups is shown in Table VI, for both local and national population. 
TABLE VI

Distribution by Age Group of the Total Population (1930) and of Tuberculosis Deaths (1934-1938)

United States and Louisville and Jefferson County

\begin{tabular}{|c|c|c|c|c|}
\hline Age Group & $\begin{array}{l}\frac{\text { Unit }}{\text { To of Total }} \\
\text { Population }\end{array}$ & $\begin{array}{l}\text { d States } \\
\text { is of Tubercu- } \\
\text { losis Deaths }\end{array}$ & $\begin{array}{l}\text { Louisville } \\
\% \text { of Total } \\
\text { Population }\end{array}$ & $\begin{array}{l}\text { Jeff. Co. } \\
\text { of of Tubercu- } \\
\text { losis Deaths }\end{array}$ \\
\hline Birth through 14 & 29 & 5 & 25 & 5 \\
\hline " 24 & 18 & 16 & 17 & 14 \\
\hline 2.5 & 30 & 40 & 33 & 42 \\
\hline 45 & 18 & 28 & 19 & 29 \\
\hline 65 years \& over & 5 & 11 & 6 & 10 \\
\hline Total & 100 & $100 \%$ & $100 \%$ & $100 \%$ \\
\hline
\end{tabular}

According to this table Louisville's proportion of deaths by age group shows very slight deviation from the proportions existing in the nation as a whole; where there are differences in proportion of deaths there are usually corresponding differences in proportion of total population. The figures in Tables $V$ and VI are based on actual number of deaths. Comparative death rates, however, are a more significant index of health conditions and a sounder suide for $r$ emedial action. The following table shows that in all the age groups the local tuberculosis death rates are righer than the corresponding national rates. Both localiy and nationally the figures progressed consecutively from the lowest rate at the youngest age to the highest rate at the oldest age.

TABLE VII

Tuterculosis Death Late per 100,000 Population; Annual sverage 1934-1938 Age Group United States Louisville Jeff. Co.

Birth through 14 years

$\begin{array}{llcl}15 & " & 24 & " \\ 25 & \text { " } & 44 & \\ 45 & 64 & \\ 65 & \text { years and } & \text { over }\end{array}$

9.8

49.3

76.2

89.1

107.4

$$
\begin{array}{r}
15.0 \\
53.0 \\
88.0 \\
104.6 \\
123.3
\end{array}
$$


Since most studies show that the Negro race has higher tuberculosis death rates than the white race and since the percentage of Negroes in the population of Louisville and Jefferson County is higher than in the country as a whole (the local ratio is 1 legro to 6 white persons; the national ratio is 1 Negro to 9 wite persons), it seemed possible that the local population make-up might account for the higher local death rates. The rates for each race therefore, have been computed separately in the attempt to discover where the most serious local problems might be.

\section{TABLE VIII}

White Tuberculosis Death Eate per 100,000 Population by AGe and Sex United States and Louisville and Jefferson County Annual Average 1934-1938

\begin{tabular}{|c|c|c|c|c|}
\hline \multirow[b]{2}{*}{ Age Group } & \multicolumn{2}{|c|}{ hiale } & \multicolumn{2}{|c|}{ Female } \\
\hline & U.S. & Local & U.S. & Local \\
\hline Birth through 14 years & 7.1 & 13.1 & 7.2 & 10.8 \\
\hline $24 \quad "$ & 25.0 & 17.6 & 39.9 & 35.9 \\
\hline $44 \quad "$ & 65.4 & 70.2 & 52.5 & 58.5 \\
\hline $64 "$ & 111.3 & 95.7 & 48.1 & 63.8 \\
\hline 65 years and over & 122.2 & 144.2 & 88.0 & 101.3 \\
\hline
\end{tabular}

\section{TABLE IX}

Negro Tuterculosis Death Rate per 100,000 Population by Age and Sex United States and Louisville and Jef ferson County Annual Average 1934-1938

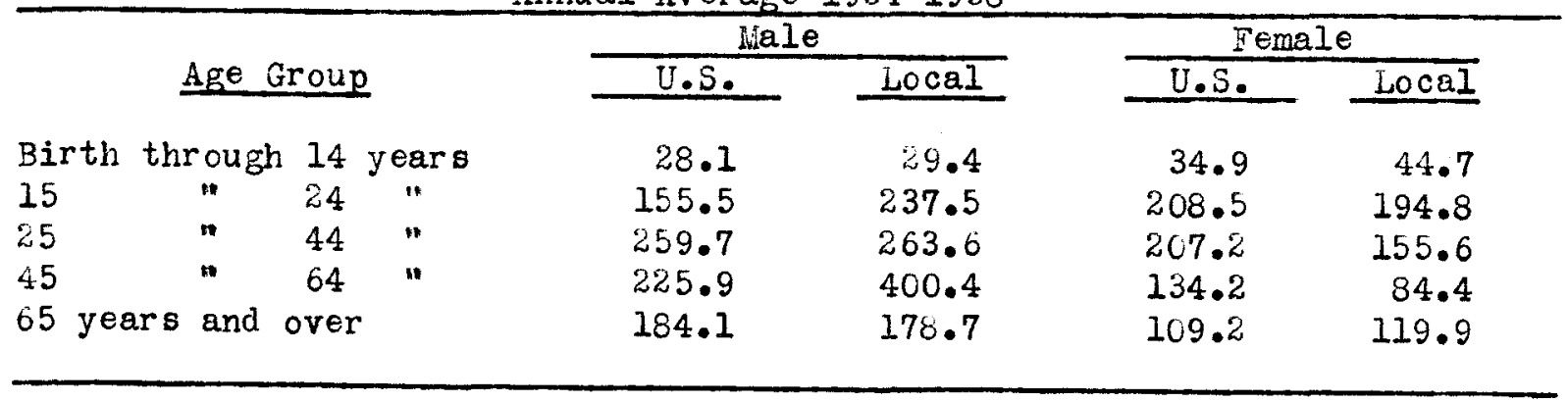

is these tables show, the local rates for both male and female children under fifteen years of age are higher than the national rates; the 
two rates approach most closely in the case of Negro male children. In the age group 15 through 24 Jears Louisvilite and Jefferson County have a slightly better rate than the country as a whole, except in the case of the Negro males.

In the age group 25 through 44 years the local rates are slightly worse than the national, except in the case of Negro females who have a distinctly favorable rate.

In the age group 45 through 64 years the white men and the Negro women have lower rates locally than nationally; the local white women have somewhat higher rates than the national rate for white women of this age; but an outstanding divergence is shown in the case of the Negro male, who has a death rate of 400.4 per 100,000 population as compared with the corresponding national rate of 225.9 .

In the age group 65 years and over the local rate is slightly higher in every case except the Negro male, where it is slightly lower. In summary, the local Negro male shows almost consistently higher death rates than does the Negro male nationally; the local Negro female shows a markedly lower than national death rate except in the case of little girls and old women where the differences, although adverse to the local group, are not wide; the local white rates follow the national white rates fairly closely, being sometimes better and sometimes worse. It would seem that both races contribute to placing the local tuberculosis death rates above the national rates, but that the Negro male presents the most serious problems, with the Negro female showing a surprisingly favorable status. 
In general the looal female rates are considerably lower than the $100 a 1$ male rates. The only groups showing the reverse ratio are the white females between 15 and 24 years of age who have death rate twioe as high as white males of simflar age, and Negro female ohildren under 15 years old who have much higher death rate than Negro male ohildren. The major deduotion from the foregoing evidenoe is that the Negro male from 15 to 65 years and to a lesser extent the young Negro fomale are the looal groups most needing intensive health effort. 


\section{E. Tuberculosis According to Geographic Area}

Poor environuental sanitation has long been considered one of the predisposing factors in tuberculosis. Dark and damp dwellings make good breeding places for bacteria of all kinds and when they are overcrowded with human beings comanicable disease has excellént opportunities to spread. of the total $1 \% 33$ persons dying from tuberculosis in Louisville and Jefferson County during the period studied there were $15 \mathrm{E}$ who Lived in the county outside of Louisville. The housing conditions where these deaths occurred are not known; within the city, however, it is possible to know whether the homes of these tuberculous patients were in areas of good, fair or poor housing conàition.

Louisville has been divided by the United States Census Bureau into eighty-nine small geographic units known as census tracts. infortunateIy, since the 1930 census was not taken by census tracts it is not possible to compute, by means of comparative ciensities of population, the comparative tuberculosis death rates of the different tracts. However, the map on page 19 shows the number of deaths occurring in each tract from 1934 to 1938 . There were three tracts, it 12 , if 14 and ${ }_{0} 60$ which furnished no deaths from tukerculosis throughout the five year period. These tracts are very thinly populated with much park and other open space.

The number of tuberculosis deaths is consistently lowest in the outer areas of the city. The majority of the tracts which rake up crescent Hill, the Highlands, South Louisville and the west Lnd had from one to nine deaths, or an average of two deaths a year. As one travels in toward the center of the city the number of deaths increases, with an annual average 


\section{LOUISVILLE}

Census Tract Map

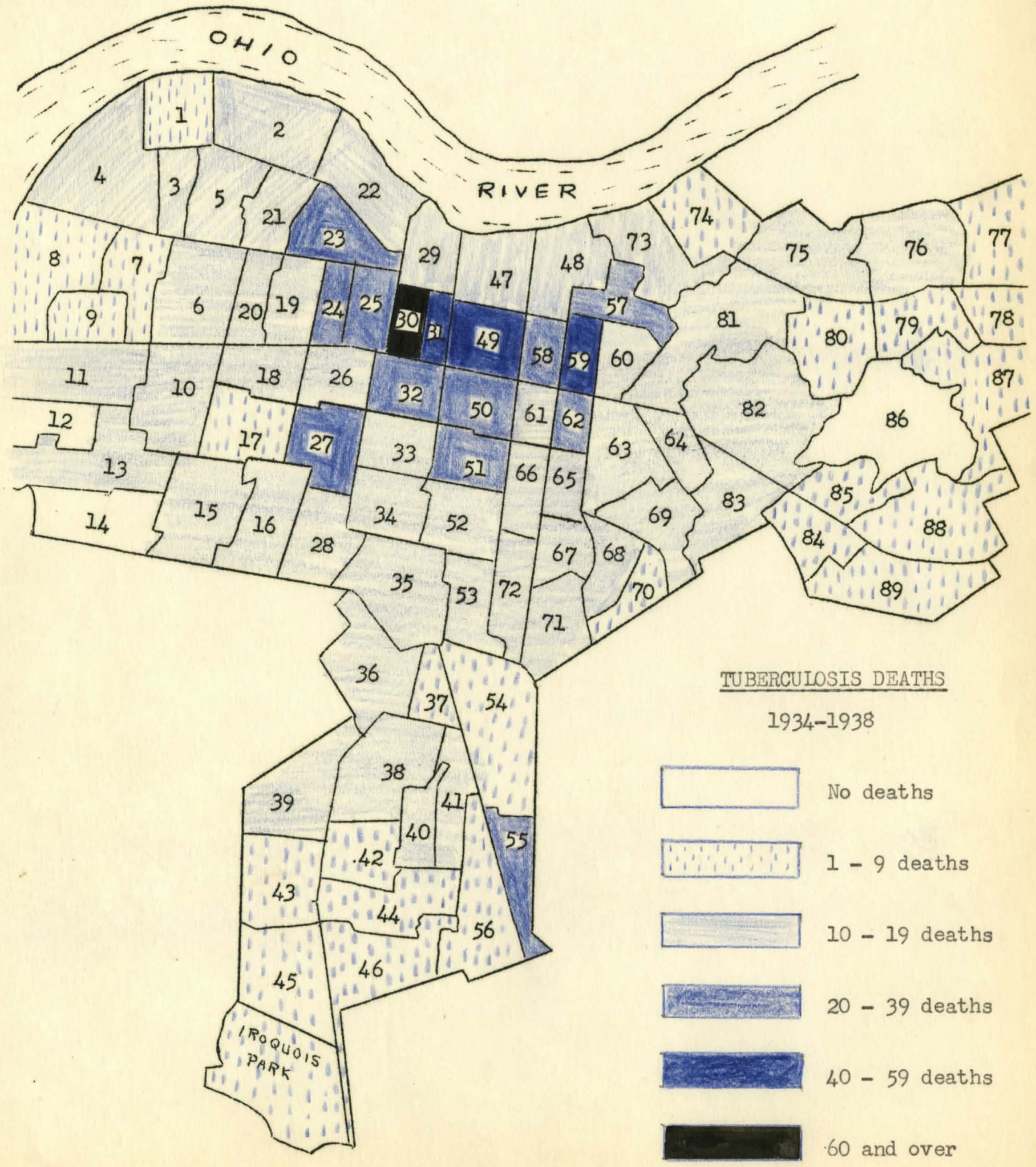


of four. In the heart of the city is census tract $\frac{\pi}{\pi} 30$, bounded by $J \in f f e r s o n$ Street and Broadway from Tenth to Fourteenth streets, with the highest number of deaths -69- in the five year period. At the time of the stuay it was 4 densely populated Negro tenement aistrict. It provided the highest number of Negro deaths -07- and the highest nuruber of children's cieaths -6- of any tract in the city.

The census tracts having the next highest number of aeaths were the adjacent 31 with 45 deaths, and the rearby 49 and ${ }^{5} 5$, each with 40 aeaths. The area inclucied in these four census tracts had an average of 9 white and 30 liegro deaths from tuberculosis each year.

The role played by the Necro in increasing the total death rate is clearly shown by the fact that the highest number of vihite deaths - $20-$ did not occur in any of these four tracts, but in "55 in Highland park. This tract also furnished the kighest number -5- of wite children's deaths. It is largely inhakited by families who have recently moved into Louisville from rural areas where there have been few facilities for tuberculosis control.

In 1938 the lunicipal Fousing Commission surveyed the condition of all dweliing units in Louisville, later classifying them as in "good condition", "needing minor repair", "needing major repair", and "unfit for hurnan habitation". There were only three out of the total eighty-nine tracts in the city which were found to contain more than two hundred houses "unfit for human habitation". These three tracts $w \in r \in \pi 30, \pi 31$ and $j 59$, the same three tracts which also had the highest number of tuberculosis deaths. Among the group of tracts having between one and two hundred houses "unfit for human 
habitation" was $i^{4} 49$, the fourth highest tract when measured by tuberculosis deaths. Tracts 731 and 449 contained nore houses in the category "unfit for human hatitation" than in any other category.

other housing data were collected about the ten tracts having the highest number of deaths from tukerculosis. These were tracts if 24,25 , $30,31,49,50,55,58,59$ and 62 . Seven of these ten containea more than 100 dwelling units classified as "unfit for human habitation". It would have been interesting to know to what extent the tukerculous patients owelt in the worst houses of the tracts, but this information was impossible to find. six of these ten tracts were in the group having the greatest number of dwelling units with three or more persons per room. Two persons per room is supposed to represent the highest occupancy compatible with minimum adecuate housing standards.

In the amount of indoor plumbing the houses in these congested, infected areas ranked fairly well. Most of the houses were tenements converted from former large one-family homes and they contained indoor toilets and running water liore frequently than the scattered small cottages in the census tracts nearer the outer city boundaries. The individual use of these toilets and sinks by one family was, however, very rare.

The following ten tracts had the fevest number of deaths from tuberculosis: if $1,12,14,45,54,70,84,65,86$ and 87 . Eight of these tracts contained no dwellings "unfit for human habitation". None of them had dwelling units where the occupancy was as high as three or more persons per room. Four of these tracts, lying on the outskirts of the city, fell in the group with the least proportion of dwellings with indoor plumbing. 
It is evident, therefore, that in Louisville there is a positive relation betwe $n$ areas of good housing anci low tuberculosis deaths, una a complete correlation between the areas of worst housing and highest number of tukerculosis deaths.

The correlation between low rent and increased amount of tuberculosis is not so evident. A most frequent rental of less than $\$ 10$ per month was found in four of the ten tracts with few tuberculosis deaths, and in five of the ten tracts with the highest number of deaths from tuberculosis. A most frequent $r \in n t$ of from $\$ 1 C$ to $\$ 20$ was found in one tract with few deaths and in three tracts with many deaths. A most frequent $r \in$ nt of over $\$ 30$ per month was found in four of the tracts with few deaths and in one tract with many deaths. Those census tracts having low rentals and also low number of deaths from tuberculosis - 113,14 end 54 - represented sparsely populated peripheral areas where comparatively few people live in small scattered houses.

In three of the four worst tracts the prevalent rents were very low. In $\# 30,31$ and 59 tre most usual rent was less than $\$ 10$ per month per housing unit. In 49 most of the units paid from $\$ 30$ to 50 per wonth, but there were numerous very low rentals in alley dweldings. In general it might be said that these rundown areas, heavily infectea with tuberculosis are not areas of high income value to their owners or to the city. These considerations played a part in the decision of the municipal Housing Commission to locate their slum clearance projects in such areas. Wore than one-third of tract $\$ 59$ is now included in the Clarkdale Housing Project for white families, while fully one-third of tract $/ 30$ and about one-eighth 
of tract 31 will soon be occupied by similar model homes for Negroes. In Louisville low rentals are found in two widely aifferent types of houses. The same rent may be paid for a small three-room cottage with large surrounding yard and individual, but outside, toilet and water facilities, as for a two-room furnished apartment in a crowded, dark tenement where several, possibly transient families use a common hallway, toilet and sink. It is thought that this fact accounts for the lack of correlation between frequency of tuberculosis deaths and low ientals, since the conditions first aescribed, although obtainable for Low rent, do not constitute realiy bad housing.

F. Tuberculosis According to occupation

occupation is popularly considered an important factor in the incidence of tuberculosis. The long-continued breathing of air cverladen with soot or sharp-eaged ust has a distinctly injurious effect in the Lungs. here detailed studies of the past occupation of tuberculous patients have been made, direct correlation has been found between the disease and occupations involving these and some other employment hazards.

It is difficult, however, from the occupational information furnished on a death certificate to determine the actual conditions of the occupation as encountered by the patient. The report that the deceased was a "foreman" or a "salesman" does not reveal much about the physical conditions surrounding his work, nor does the term "railroad employee" indicate

1. National Tuberculosis Association, Facts and Figures About Fuberculosis, p. 18 
whether the man had an indoor mechanic's job or was watchman at a crossing. Confusion also results from the shift in occupation frequently made by tuberculous patients from the hazardous employment hich may have accelerated the disease to an easy type of work which the patient hay have feIt himself able to perform, but under which he may have finally succumbed. All of these factors, and others which appear later, make it impossible to araw reliable conclusions from any study of the occupation as stated on the death certificates of persons who have died from tuberculosis. Certain figures can be presented indicating in what general occupational groups the greatest number of deaths occur.

of the 1233 persons dying from tuberculosis in Louisville and Jefferson County in the years 1934-1938 there were 1106 over fifteen years of age and presumably able to have worked at some time prior to their deaths. on 375 certificates, representing practicaliy one-third of these persons, there was no report regarding occupation. It is not known whether the deceased had never worked or whether there was negligence in filling out the death certificate.

The highest number of those whose occupation was recorded wert housewives, of whom there were 217 or $19 \%$ of the total number of deaths of persons over fifteen years of age. Not much significance, however, can be attached to this finding since all married and unmarried women not employed outside of their own homes were probably listed as housewives.

Among the other definitely stated occupations, unskilled labor had the highest number of deaths, 155 or $13 \%$ of the total. When rates for the races were separately computed it was seen that $25 \%$ of Negro deaths 
TABLE XI

Occupation of Those Over 15 Years Dying from Tuberculosis Louisville and Jefferson County, 1934-1938

\begin{tabular}{|c|c|c|c|c|c|c|c|c|c|c|}
\hline Occupation & Male & $\frac{\text { White }}{\text { Female }}$ & TotaI & Male & $\begin{array}{r}\text { Negro } \\
\text { Femele }\end{array}$ & TotaI & $\begin{array}{l}\text { Total } \\
\text { Nale }\end{array}$ & $\begin{array}{r}\text { Total } \\
\text { Female }\end{array}$ & $\begin{array}{l}\text { Grand } \\
\text { Total }\end{array}$ & $\begin{array}{l}\% \text { of } \\
\text { Total }\end{array}$ \\
\hline Business Owner & 12 & 1 & 13 & 0 & 0 & 0 & 12 & 1 & 13 & 1.1 \\
\hline Clerical Work & 28 & 19 & 47 & 0 & 0 & 0 & 28 & 19 & 47 & 4.1 \\
\hline Domestic Service & 1 & 9 & 10 & 13 & 17 & 30 & 14 & 26 & 40 & 3.4 \\
\hline Factory Work & 8 & 5 & 13 & 0 & 2 & 2 & 8 & 7 & 15 & $I ; 3$ \\
\hline Farmer & 28 & 0 & 28 & 3 & 0 & 3 & 31 & 0 & 31 & 2.7 \\
\hline Housewife & 0 & 180 & 180 & 0 & 37 & 37 & 0 & 217 & 217 & 18.6 \\
\hline Personal Service & 21 & 5 & 26 & 48 & 3 & 51 & 69 & 8 & 77 & 6.6 \\
\hline Professions & 15 & $1 I$ & 26 & 1 & 1 & 2 & 16 & 12 & 28 & 2.4 \\
\hline Salesmen & 27 & 0 & 27 & $I$ & 0 & 1 & 28 & 0 & 28 & 2.4 \\
\hline Skilled Trades & 87 & 3 & 90 & 14 & 0 & 14 & 101 & 3 & 104 & 8.9 \\
\hline Unskilled Labor & 45 & 0 & 45 & 110 & 0 & 110 & 155 & 0 & 155 & 13.3 \\
\hline Miscellaneous & 33 & 1 & 34 & 2 & 0 & 2 & 35 & $I$ & 36 & 3.1 \\
\hline No Report & 75 & 109 & 184 & 94 & 97 & 191 & 169 & 206 & 375 & 32.1 \\
\hline Total & 380 & 343 & 723 & 286 & 157 & 443 & 666 & 500 & 1166 & 100.0 \\
\hline
\end{tabular}


were listed as unskilled laborers, compared with $6 ;$ of the white group. This fact calls attention to the accompanying factors of low income and poor housing conditions which make the unskilled laborer an easy target for disease.

Next in rank came the skilled trades, then those engaged in personal service including janitors, porters, waiters, bartenders and chauffeurs. Olerical workers were sixth in percentage and persons engaged in domestic household services were seventh. The exact number of people ehgaged in the different occupations is shown in Table XI on page 25. Unfortunately it is not possible to compare this local ranking with the rank of the respective occupations in the total population. The U.S. Census reports the industry in which a man is employed rather than the actual type of work that he does. For example, the "Chemical Industry" might include common laborers, clerical workers and professional men, each of them exposed to varying hazards. If the medical specialists should become convinced of the importance of occupation as a predisposing factor in the incicence of tuberculosis, it would be well for health authorities to insist on a more accurate recording of occupations and industry in which the deceased had been engaged. Such findings as are reported in the preceding paragraphs merely corroborate the popular impression that those in the lower economic brackets are the most frequent victims of tuberculosis.

G. Larital Status of Persons Dying f om Iuberculosis

The marital status of tuberculous patients has significance in two directions. First, from the cominicable disease angle; a person who is married and may have children has greater opportunity to spread the dis- 
Maritel Status of Persons 15 Years olderDying From Tuberculosis Louisvilie and Jefferson County, 1934-1938

Kace Sex Single Niarried Widowed Divorced No Report Total

$\begin{array}{lrrrrrr}\text { White lale } & 121 & 196 & 37 & 19 & 7 & 380 \\ \text { White Female } & 93 & 166 & 59 & 21 & 4 & 343 \\ \text { Negro Viale } & 122 & 117 & 23 & 18 & 6 & 286 \\ \text { Negro Female } & 62 & 60 & 25 & 9 & 1 & 157\end{array}$

$\begin{array}{lllllll}\text { TotaI } & 398 & 539 & 144 & 67 & 18 & 1166\end{array}$

TABLE XIII

Warital Status of Total Population

And of Persons Jying From Iuberculosis, by Percentage

Louisville and Jefferson County Residents 15 Years of Age o Older

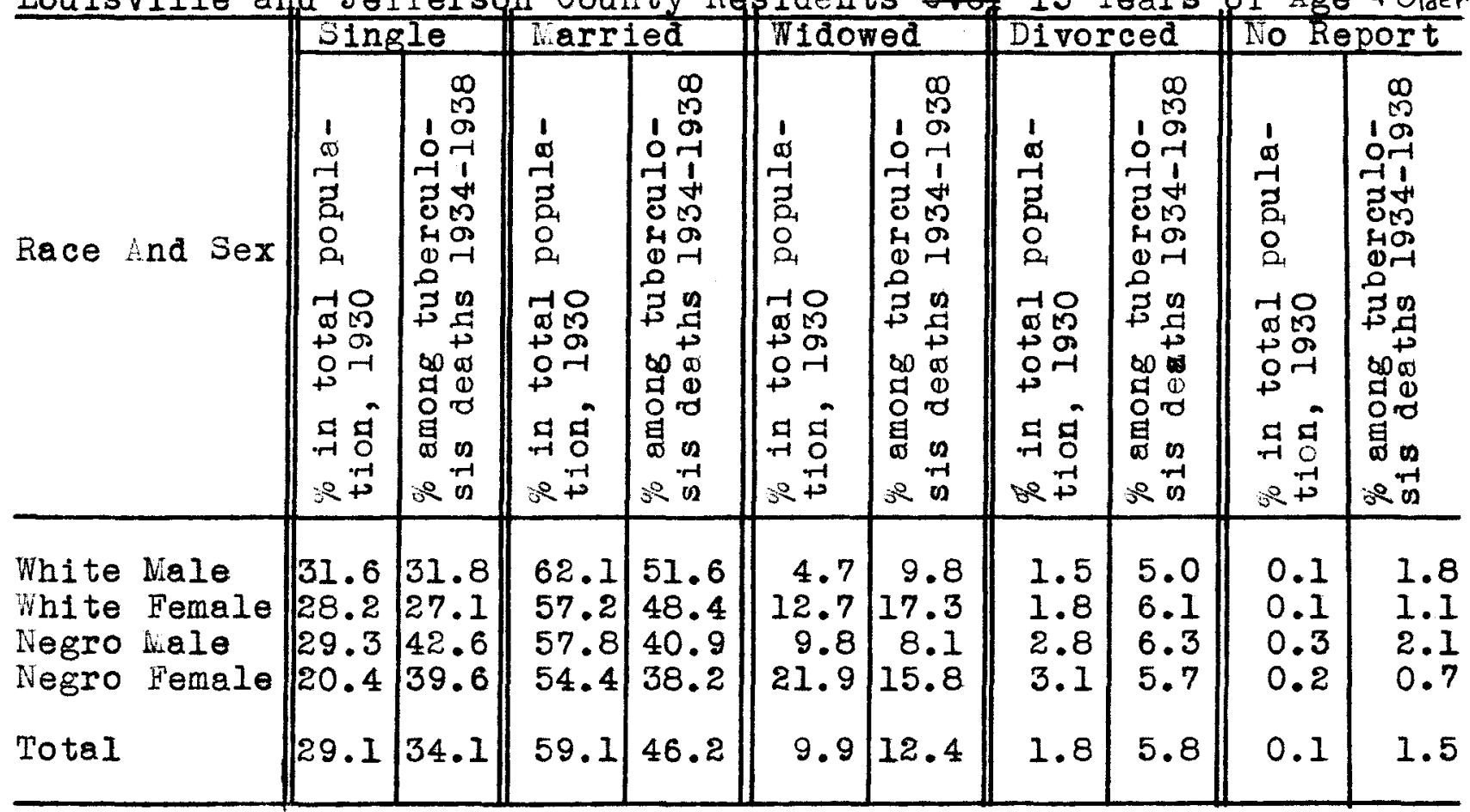

\section{TABLE XIV}

Death Rates per 100,000 Pop. Of Tuberculous, By Marital Status Louisville and Jefferson County, 1934-1938

\begin{tabular}{|c|c|c|c|c|}
\hline Race And sex & single & Married & vidowed & Dirorced \\
\hline $\begin{array}{l}\text { White Male } \\
\text { White Hemale } \\
\text { Negro Male } \\
\text { Negro Female }\end{array}$ & $\begin{array}{r}71 \\
56 \\
423 \\
290\end{array}$ & $\begin{array}{r}58 \\
49 \\
210 \\
105\end{array}$ & $\begin{array}{r}144 \\
75 \\
249 \\
109\end{array}$ & $\begin{array}{l}234 \\
199 \\
707 \\
281\end{array}$ \\
\hline Total & 103 & 67 & 108 & 275 \\
\hline
\end{tabular}


ease because of the close contact of farily life. second, from the point of view of economics; a married tuberculous patient is apt to have cependants for whom relatives or the colnrunity rast provide if the breadvinner or housekeeper is incapacitated.

It is therefore interesting to note that among the lloc persons over fifteen years of age who died from tuterculosis in Louisville and Jelferson County from 1934 to 1938 there vere 539 persons, or over $46 \%$ of the total who were married. This is a lower percentage than obtains among the general population. The 1930 Census showed that $59 \%$ of the total population of marriageable age in Louisvilie and $J \in f f \in r s o n$ County were married. Among the white tuberculous patients a higher proportion were married than among the Negroes, the figures being 45, of the whites and $46 \%$ of the legroes, as compared with $60 \%$ mar ied anong the total aoult white population and $56 \%$ married among the total adult Negro population. It is not known whether the fact of having tuberculosis acted as a deterrent to narriage in a sufficient number of cases to cause this reduction. Lowever, since the greatest number of tuberculosis cases was found in the most overcrovded areas of the city, the fact that fewer than average of these cases were married has probably meant that they have caused $f \in w \in r$ new infections than would have occurred if there had $b \in \in n$ the average proportion of marriages umong them. We do not know how many children were involved in such marriages as did exist. In adcition to the 539 who were married at the time of their death, there were 211 persons who were vidowed or aivorced. These also may have had families living with them while their disease was in an 
active stage. The percentage of those nidowed was approximately equal for both the white and Negro races. In each race, however, a higher number of women than of men had lost their spouse, only $9 \%$ of the men having been widowers whereas $17 \%$ of the women were widows. This same difference is seen in the general population, where $6 \%$ of the men were widowers and $14 \%$ of the women were wiciows; one explanation way be the fact that more women than men live on into the upper age groups. This fact was shown to be true for tuberculous patients by the figures in Fable $V$.

On a small number of the death certificates there was no record of marital status, but 398 or $34 \%$ of the total over fifteen years of age were registered as single. This is a higher proportion of unmaried persons than obtains in the general population as found by the $1930 \mathrm{c} \in \mathrm{n}-$ sus, which gave $29 \%$ as the proportion of the local unmarried. A considerably larger percentage of llegro than of white tuberculous patients was single. only $30 \%$ of the whites were unuarried, which was the exact percentage of single persons in the total population. Anong the Negroes $42 \%$ were single as compared with $25 \%$ single in the total Negro population. The data on which these statements are based are shown in Tatle XII and rable XIII on page 27.

A comparison of the average annual tuberculosis death rates for those of aifferent warital status, presented in Table XIV, shows that the married group has the lowest cieathrates, both for white and Negro and for male and female. harried wite females have the lowest rate for any group, while the maried Negro females have the lowest rate for uny group of their race. luch the highest rate of all was for the divorced 
and the single iegro male, indicating the probability that the most neglected individual in the comrunity, from the point of viev of health, is the drifting, adult male fegro. The difference in the tuberculosis death rates of the two races is most apparent in the rates for single men, the rate for single Negroes being six times that for single white men. In general rates for the divorced were the highest of any group, but there were comparatively $f \in w$ persons involved in that group.

E. Tuberculosis According to Place of Death

The preceding sections of this report have presented data on the group of those dying frort tuberculosis in Louisville and Jefferson County, indicating that this disease affects those in the lowest income levels more frequently than those who are self-supporting or affluent. The material in the next two sections gives more definite information as to the number of those persons who were a airect charge on the city, the county or the state for their complete or partial maintenance either in institutions or by $r \in l i \in f$ agencies.

The first item to be considered will be the place of death as registered on the death certificates. of the $1 \neq 33$ deaths in Louisville anc Jefferson County from tuberculosis there were 840 or $69 \%$ who died in hospitals and 385 or $31 \%$ who died at rome.

A relatively srall number of tukerculous patients died in private hospitals - $7 \%$ of the total white deaths and $2 \%$ of the total Negro deaths. There are two major reasons for this fact; tuberculous patients are ill for a long time before death and few families can neet the corres- 
pondingly high cost of private hospital care; in the second place private hospitals are reluctant to admit known cases of tubercuiosis because of the infectious nature of the disease.

The only free tuberculosis sanatorium in the community, available to local patients, is Waverley Hills, where 502 or $41 ;$ of the total deaths occurred. Throughout the United states in 1933 only $22 \%$ of tuberculosis deaths occurred in sanatoria. Some communities, however, seno early rather than terminal cases to their tax-supported institutions, cases which after some weeks of resicience can be discharged to the community as practically cured. Such comrunities might have a smaller proportion of deaths in their sanatoria yet an equally good tuberculosis control record.

Although waverley fills is the local specialized hospital for tuterculosis there were also 204 deaths from that disease at City hospital. Some of these had been persons on the wuiting list for the sanatorium, others were patients brought to City Hospital with some other acute condition, who were found to be tuberculous after admission.

Another large group of tuberculous patients was found at LakeIand, the Central State rospital for the Insane. There were 82 deaths of Louisville and Jefferson County residents at Lakeland, or upproximately 16 deaths a year, although the average number of local patients there at any one time is only $12 \mathrm{C}$ and the turnover is slow. one of the deaths from tuberculosis there was that of an attendant who had been siving constant daily care to the mental patients.

1. Journal of the American Nedical Association, Dec. 7, 1935. p.1655 
All three of these institutions, City lospital, waverley hills, and Lakeland are tax-supported and together they cared for 788 persons or $64 \%$ of those who died from tuberculosis in the five year period. Separating tie percentages by race we find that 79 ; of the Negro deaths and $55 \%$ of the white deaths occurred in these three institutions. The number of deaths at Waverley Hills and City Fospital holds fairly constant for each of the five years; at Lakeland, however, there was an increase with succeeding years, especially among female Negroes.

Institutions do not measure all of a comunity's responsibility for tuberculous families. There are other public and private social and health agencies which give relief and service to such families.

\section{Comrunity Agencies Serving the Tuberculous}

The Social Service Ixchange is an information bureau with which many social and health agencies register some or all of the families coming under their care, in order to be able to exchange information akout the families and to know what other agencies are helping them. The agencies using the Exchange fall into three groups: those giving relief; those providing a health service; and certain other social agencies providing recreational and character-building opportunities or corrective care for their clients.

All of the names of persons dying from tuberculosis during the five year period 1934-1938 were checked through the waster index at the Exchange to find out if their families were known to any of the agencies using the Exchange. Although the Exchange is keing used to an increasing 
extent some agencies do not register all of the families known to them. The following findings, therefore, mst ke taken as a conservative estimate of the contacts of the families of the tuberculous with the relief, health and other social agencies of the city and county

of the 1233 tuberculous persons involved, the families of 379 , or $31 \%$ of the total, were found to have been known to relief agencies, including the lunicipal Bureau of Social service, the Jefferson County Department of velfare, the did to Dependant Children, the Family Service organization, the Jewish welfare Federation, the st. Vincent de Paul Society, the Salvation Army and a $f \in W$ others. The proportion known to these agencies closely approximates tive "one-third of a nation" often estinated to belong to the underprivilexged group. The number of families known to relief agencies increased with succeeding years, having been $24_{i}$ of the total in 1934 and $34 \%$ in 1938 . it higher proportion of Negroes than of white persons was known to these agencies, $38 \%$ of the former and 26, of the latter. Woh race, however, showed a progressive increase in registration for dependancy. It woulo be interesting to know whether the increase in dependancy among the general public during this period was as great as the increase among the tuberculous, or whether the latter were peculiarly unable to continue successful competition for self-support under the difficult conditions of these depression years.

Although the census tract with the highest number of deaths from tuberculosis also had the highest number of those families on relief, it did not have the highest percentage of its tuberculous families on $r e-$ lief. Tracts $\$ 45$ and $\neq 87$ had $100 \%$ of the families in which there had been 
deaths from tuberculosis on relief, but as they each had only one death the actual number of families was small and probably insignificant. In the following census tracts, scattered widely throughout the city, $50 \%$ or more of the families having deaths from tuberculosis were known to relief agencies: if $4,18,20,22,29,33,35,36,39,46,70,72$ and 74. of these ${ }_{i f} 22$ had the highest proportion on relief, 13 out of a total of 19 families.

Inquiry into the marital status of the tuberculous patients known to relief agencies reveals that except for the Negro male the unmarried person was less likely to be known to relief agencies than any other group. Among the Negroes there was a smaller percentage of widowed and divorced men on relief than of single men. There was a higher percentage of tuberculous white widowers known to relief agencies than any other white male group, although the white married men had alrost as high a proportion. The married white female and the married Negro of botin sexes were known to relief agencies more frequently than the single, widowed or divorced of their respective groups. These facts confirm and reemphasize the earlier findings that tuberculosis deals its heaviest blows at persons in the early and middle years of life when responsibility for the support of others is heaviest.

Unfortunately it is not possible to learn just how much in dollars and cents was spent on the families known to relief agencies. Some of them were totally dependent, others were visited by the relief worker in order that a member of the family might be certified for WPA, others nay have been known to the agency but not considered in need of $r \in l i e f$. 
Even among those accepted for relief there would be considerable variation in the grants received, depending on what assets the family itself possesced and which agency was helping them. All that can be stated with certainty is that over a period of five years a third of the families of Louisville and Jefferson County in which there were deaths from tuberculosis considered themselves in need of financial assistance. This proportion has increased progressively throughout the five years.

There were 250 tuberculous families, approximately $20 \%$ of the entire number, known to social agencies other than relief; for example those agencies interested in the correction and prevention of social breakdown, including settlement houses, the Louisvilie and Jefferson County Chilaren's home, the Juvenile Court and a few others. The proportion of families coming to the attention of these agencies also increased during the five year period, from $16 \%$ in 1934 to $24 \%$ in 1938. A higher proportion of liegroes than of whites were known to these agencies and the rate of increase was also faster for them.

The census tracts having the highest number of tuberculosis deaths and of relief agency registrations had also the highest number of families known to other social agencies. Tracts if 30,31 and 59 had ten or more such registrations. Curiously, tract 49 , which is in one of the most congested Negro sections of the city, had only three of its forty tuberculous families known to relief agencies and only two known to other social agencies.

The health agencies were naturally the group registering the highest number of tuberculous families at the Social Service Exchange, 
although they do not register all the cases known to them. These agencies include the Visiting Nurse Association of Louisville, the Louisville Tuberculosis Association, the City Health Department and City Hospital, the Waverley lills Sanatorium and Clinics and the Central State Hospital. Altogether they registered 473 families, or $38 \%$ of the total number of families with tuberculosis deaths. It is interesting to note that $37 \%$ of the families they registered were known to heaith agencies only, while $23 \%$ of the families registered by relief agencies were known to relief agencies only, and $12 \%$ of the families registered by other social agencies were known only to that group. From these figures it would seem probable that many of the families known to waverley Fills, Central state Hospital, etc., do not have problems outside of the health field, while those families known to $r \in l i e f$ and other social agencies are apt to need health services also. In other words, poor health as $\in v i d e n c \in d$ by tuberculous infection, although ranging through all economic Ievels, is more consistantly found to accompany poverty, overcrowded living conoitions and parental neglect of children.

Over the five year period there was a slight increase in the number of families known to the health agencies and registered with the Social Service lxchange. There were $35 \%$ of the total tuberculous families so known in 1934 and $39 \%$ in 1938. This increase occurred almost entirely among the Negro families and may reflect the increasing knowledge about the families on the part of the health agencies due to the intensive health education campaign among the Negroes in recent years.

The isolation of certain groups from contact with comranity 
forces which might be helpful to them in combatting the handicap of tuberculosis is most clearly brought out by the enumeration of those who apparently had never been known to any social or health agency A Among both white and Negro, male and female, the married patients wert more apt to be known to health agencies than the single, widowed or divorced. There were $f \in$ wer unarried females registered as known to health agencies in 1935 , 1936, 1937 and 1938 than in 1934. Since there were numerous deaths in all these years among young unmarried women it would seem that aore attention could viell be paid by health agencies to them. nttention should also be given to the divorced and single males of both races; wen with families were apparently reached through their families; the single, the divorced and the widowed are more apt to be unknown in the community, a danger to themselves and a potential danger to others.

There were three areas in the city containing a number of deaths from tuberculosis in families who had never been registered by any reaith agency. These areas were: the Scuth Ind, including census tracts if 42,44 , and 45 ; the west End, with census tracts $70,9,11$ and 17 ; and the righlaris, with tracts $; 84$ and 85 . These are predominateiy wite resioential neightorhoois, without $r \in$ sidents of great wealth. Tract $i 64$ in Germantown with six deaths and tract +61 in the central part of the city with seven deaths, none in families registered by health $a_{6} \in n c i e s$, woula also seem good fields for more intensive preventive health work. As was mentioned earlier in this section, there were nany of the 1233 total persons dying from tuberculosis who were known to social and health agencies, but were never registered by them with the social 
Service Exchange. It is possible, however, to allocate some of these persons to charitakle institutions when the death certificate jives such institutions as the place of death. In order to obtain the total picture of the comanity's financial responsibility for tuberculosis one rust, therefore, add to the list of unduplicated registrations at the Exchange the nanes of non-registered persons reported as dying in Louisville tax-supported or commanity-supported institutions. i count of the foruer oroup shovs that there were 627 different persons whose families were registered as known to one or more of the local health, relief or otker social agencies. In addition there were 368 individuals not known to the Social Service Exchange, but shown by their death certificares to have died from tuberculosis in some public or charitable institution. The total of these two groups is 995 persons, revealing that $80 \%$ of the total deaths from tuberculosis in Louisville and Jefferson County, over a five year period, were of persons who had been dependent, to greater or less degree or for shorter or lcnger pericds on community resources. only 238 , or $20 \%$ of the total deaths, were of persons known exclusively to private hospitals and family physicians. Of course it is not true that tuberculosis alone caused all of the comunity expense represented by that situation, but the conclusion is inescapable that tuberculosis was responsible for a large part of it. Among the white patients the reliance on the comunity is increasing. In 1934 there vere $72 \%$ of the total number of persons dyine from tuberculosis who had been treated in publicly supported clinics or hospitals or were known to some social or health agency, whereas in 1938 there were $78 \%^{\circ}$ who had such contacts. Among the Negroes, however, the trend was 
in the opposite direction; $92 \%$ had been cared for by public or private agencies in 1934 and only 85 in 1938. The difference is mainly accountea for by the progressively smaller number of male Negroes dying in public institutions, the decrease during the five year period being from $90 \%$ to $63 \%$. The percentage of Negro females cying in public institutions vas the same in 1938 as in 1934, while the percentage for both sexes of the white race cared for in public institutions increased during this period. It is only in the institutional care of the male Negro that there is a decrease of public expense, since we saw in a preceding paragraph that wore male Negroes were known to relief and social agencies in 1938 than in 1934. It would probably in the end be less expensive to the comanity to search out and hospitalize these sick men rather than to let them continue to live in homes scattered throughout the city, supported in increasing numbers by social and relief agencies and spreading the infection of their disease.

Throughout this study we have used the combined figures of Louisville and Jefferson County, but it may be of interest to present the information contained in this section separately for city and county. The following table shows that the county had a smaller registration.

TABLE XV

liegistration of Tuberculous patients at Social Service Exchange Louisville and Jefferson County, 1934-1938

\begin{tabular}{llc}
\hline & $\frac{\text { Percent of Total Tuberculous Families }}{\text { Louisville }}$ & $\frac{\text { Iefferson County }}{33}$ \\
Negistered by relief agencies & $\frac{16}{10}$ \\
registered by other social " & 20 & 26 \\
liegistered by health & 40 & 74 \\
Known to some agency or institution & 82 & 26 \\
Unknown to any " " " & 18 &
\end{tabular}


IV. Agencies fiesponsible for Tuberculosis and Their Cost 


\section{Agencies responsible for Care of Tuberculosis and Their Cost}

There are two agencies in Louisville and Jefferson County whose primary responsibility is the treatment and prevention of tuberculosis in trat area. One of these is supportea by public funds and one by private contributions. The public agency is the Board of luberculosis Hospital (responsible for averley Fills Sanatorium and clinics), created under a permissive state Statute, guite separate from tne City or County Health Departments. Its budget is met from joint city and county taxes and appointments to the Board are wade by. the City realth officer and the 1

County Judge. The Board maintains the only free sanatorium, available for local patients, situated in the county; it also maintains several tuberculosis clinics, situated within the city limits; city ano county patients are admitted to the sanatorium after examination at the clinics and recommendation by the clinic director. only bona fide residents of the city and county are eligible for admission, although there have been a few instances of emergency non-resident admission.

The sanatorium has a total capacity of 520 beds, of which 413 are for white patients and 117 for Negroes. Accoroing to the accepted de-

1. Larly in 1942 , between the time of writing this thesis and its acceptance by the faculty of the University of Louisville, the Kentucky State Legislature passed a bill which abolished tire Louisville and Jefferson County Iealth Departments and the Board of Tuterculosis Hospital and created a new agency, the Louisville and Jefferson County Board of rieath, with responsibility for all the duties of the three former agencies. This Board consists of seven members, the County Judge and the City liayor, ex-officio, and five citizens appointed jointly by the ex-officio merbers; the appointed members will serve for staggered four-year terms. This Board will form poijcies for all health work of the city and county, including the city Iospital and averley Sanatorium; it vill appoint a director of health who will administer the amalgamated services. 
sirable ratio of two sanatorium keds for each annual death from tuberculosis, the area studied would require only 494 beds, 308 for white patients and 186 for Negroes. Although the local provision for Negroes is not in accord with the standard, it is more generous than is found in anj other city in the south.

The average length of stay of each patient at the sanatoriua in the years 1934-1938 was 368 days or slightly over a year per patient. The length of stay increased during the five years of the study, being 342 days per patient in 1934, 368 days in 1935, 397 days in 1936, 359 days in 1937 and 375 days in 1938. This period was considerably longer than the average stay of 173 days per patient, reported for public sanatoria in 1934. During the five years studied the annual average cost of maintenance of the sanatorium was $\$ 378,813$, or $\$ 2.67$ per day per patient. ihis is a slightly lower figure than the $\$ 2.42$ given by Dr. Hiscock as the mean cost per patient day in twenty-five public city tuberculosis sanatoria in 1935. It is disturbing, however, to find that the highest expense of the sunatorium in any $y \in a r, \$ 386,895$, and the highest cost per patient day, $\$ 2.14$, both occurred in 1938, when next to the lowest number of patient days' care was given. In this sume year the percentage of Negro male deaths in their own homes was twice as high as in any other year, while the Negro male deaths at averley fills Sanatorium was the lowest of any year.

Alt ough the daily cost per patient at waverley sanatorium was lower than average, the longer than average stay of patients there made the

1. Journal of the American Medical Association, Dec.7, 1935; No. 105; p. 1855

2. Hiscock, Ira V., Comrunity Health Organization, p. I2I 
cost per patient amount to $\$ 762$, compared with the average cost per patient in the public sanatoria of other cities, as computed from Dr. Miscock's figures, of approximately $\$ 420$.

The Board of Tuberculosis Hospital also supports the clinics where suspected tuberculous patients are examined and active or arrested cases are given periodic physical recheck. Nurses on the payroli of these clinics visit the homes of the patients giving bedide care where needed, reminding clinic absentees to return, and teaching heulth principles with especial emphasis on the prevention of the spread of tubercular infection. The average annual cost of the clinic and nursing service in the years 1934-1938 was $\$ 32,843$. The appropriation allotted to clinic services rose gradually during the five year period, from 30,499 in 1934 to $\$ 34,898$ in 1938. It is interesting to note that the fealth Survey of Louisville made by the american Fublic llealth Association in $1935 \mathrm{r} e$ comrnends that a larger proportion of the Board of Juberculosis lospital funds be spent on the preventive and clinic services.

Altogether Louisville and Jefferson County assigned an average annual sum of $\$ 411,056$ of public tax money, equivalent to $\$ 1.16$ per capita of the total population, for the prevention and cure of tuberculosis.

It is impossible to estimate the aduitional sum of public money spent for care of the tuberculous in the City Hospital and at central state Eospital, but it was a considerable amount since the records show that an annual average of 57 patients died from tuberculosis in those public bospitals. .

1. Survey and Appraisal of the Health Activities and Needs of Louisville, Kentucky, (1935) pp. 36 and 37 
Wile the hospitalization, clinic and home nursing care of the tuberculous is provided out of tax funds, the most active program of health education directed specifically at the prevention of tuberis culosis, carried on by a privately supported agency, the Louisville liuberculosis Association. This agency derives its income partly from the Comanity chest and partly from the Christmas seal sale. Its average annual expenses for the five year period 1934-1938 were $\$ 17,490$. Its program during this period included tuberculosis case-finding through free physical examinations of industrial workers and selected groups of school children; visits to the families of those who had died from the disease, in an attempt to get all contacts exumined; vocational rehabilitation of discharged sanatorium patients; health education through moving pictures, radio talks, lectures, institutes, newspaper articles, posters, window displays, essay contests and individual intervievs; wany pamphlets and letters to special groups were also distributed.

It is impossible to make rational comparisons between the costs of different agencies engaged in this type of work. wide variety in the training and consequent salaries of personnel, and in equipment for educational work, flexibility in the promotion of one phase of the work in one year and another in another year, add to the value of the private agency's contribution to control of tuberculosis, but render comparison along financial lines of little value. The national reputation of the Louisville Tuberculosis Association for the scope of its program is excellent; its budget among that of private tuberculosis agencies of other southern cities is high. 
V. Non-Resicient Ruberculosis 


\section{Deaths From Tuberculosis Among Non-Fiesidents}

During the five-year period 1934-1938 there were 145 persons listed as non-residents who died from tuberculosis in Louisville and Jefferson County. Since only residents of the city and county are eligible for admission to the sanatorium it is arth while to inquire what was the status of these non-residents and whether they constituted an especial source of infection to the comanity because of inadequate facilities for their care.

The death certificates show that 52 , or 36, , of the 145 died at Central state Fospital. This hospital receives mentai patients from the entire eastern portion of the state and it is inevitable that there should be some tuberculous among them. Since the patients do not leave the hospital grounds they are not apt to be of much danger to the general population of the area. However, during the period of this study there was no attempt to segregate the tuberculous from the other patients within the hospital; in fact one of the deaths from tuberculosis at the hospital was that of an attendant who had been on active duty with the patients until shortly before his death. Under such conditions it may well be that some of the Louisville and Jefferson County residents (some of whom go to the hospital as children) may have contracted the disease there. To this extent the non-resiaent tuberculosis patients at Central state Hospital were a menace to Louisville and Jefferson County residents.

Hazelwood, the only state-supported tuberculosis sanatoriun in Kentucky, is located within Jefferson County, although local residents are not usualiy admitted to it. During the tibe years 1934-1938 there ciied in trat 
institution 34 persons, or $23 \%$ of the total non-resident tuberculosis deaths. Since this hospital is eruipped specifically for the treatment of tuberculosis it is improbable that its patients would be a danger to the coraunity.

There was another group of 34 persons, $33 ;$ of the total nonresident tuberculosis deaths, who died in private hospitals in Louisville. It is not the practice of trese nospitals to adwit tubercuious patients, nor is it usual, because of the expense, for persons with long chronic ilinesses to go to these hospitals. It nay therefore be assumed that these deaths were of people who had come to the hospital already sericusly ill from tuberculosis or some other disease. Eecause of their protably short sojourn in the city and of the trained nursing care given in a hospital these people would not have had opportunity to infect many local persons. These three hospital groups accounted for 120 patients, or $82 \%$ of the non-resicient tuberculosis deaths in Louisville and Jefferson County during the five yeurs uncier study. Altrough non-resident they cannot be considered irresponsible transients, nor do they constitute a problem for Whom the local health authorities need feel concern.

Findings on the rewaining twenty-five non-resicients who died from tuterculosis are not so satisfactory. Eight died in the Chilciren's Fospital, four each at the City fospital and at the larine fospital, three at waverley Fills Sanatorium, one at the Kentucky Children's jome, one at the Puritan Apartments, and concerning four the death certificates failed to report the place of death. Nineteen out of the twenty-five vere residents of the state of kentucky, five were from other states and the ori inal home 
of cne person was recorded as unknown. hll of the institutions where these non-residents died are maintained out of taxes or charitable funds for the low-income group and, in un emergency, will admit transients. Since free hospitalization of the tuberculous is practically non-existant in other parts of the state, the twenty persons who died in these institutions may have come or been brought to the city in the hope of receiving such care there. How long they may have lived with relatives or in boarding houses before entering tre institutions is not known, but there is a great possibility of their raving infected nuruerous local people auring trat period. of the four persons who died at unreported addresses within the city nothing definite is known, but it may be assured that trey too had been a source of danger to their associates for sone time prior to their death.

This section of the study inoicates that approximately five non-residents annually come to Louisville in an advanced stage of tuberculosis without financial means to care for themselves, and die in some public or charitable institution or at an unknown acidress in the citye 
VI. Problems Fresented by Tuberculosis in Louisville and Jefferson County 
VI. Problems Presented by Tuterculosis in Louisvilie and Jefferson County

The foregoing pages have given in some detail the outstanding facts in the tuberculosis situation in Louisville and Jefferson County during the years 1934-1938. Frow them a sumary balance sheet can be arawn up with items on both the asset and liability sides. Among the assets the following items may be listed:

1. Although the total tuberculosis death rate is higher locally than nationally, detailed breakdown by sex, race and age shows several local groups with rates better than the corresponcing national rates.

2. There is an especially low local rate for female Negroes from 15 to 65 years of age.

3. There is a low local rate for young white adults of both sexes.

4. The local anatorium, jointly supported by city and county, provides more than the standard requirement of beds for tuberculous patients.

5. There is an unusually generou proportion of beds for the use of Negro patients.

6. The sanatorium has a good reputation for the quality of its medical $\operatorname{car} \epsilon$.

7. During the period studied there was a continuous rise in public and private funds appropriatea for preventive services in the control of tuberculosis.

8. The program of the privately supported Tuberculosis Association has a high national reputation.

On the side of liabilities there are some obvious problems with 
equaliy obvious solutions; in other cases the problems are obvious, but the solutions require more careful consideration and more complicated action. The problems by themselves stack up somewhat as follows:

1. The local death rate from tuberculosis is higher than the national death rate and than the average for cities in the same population class as Louisvilie.

2. Only one-fifth of all local tuberculosis deaths come from the Eroup able to provide private physicians and private hospital care; four-fifths of the families where tuberculosis occurs are known to social or health agencies or to public institutions.

3. Certain areas in the city having numerous deaths among low and midde income families scem, in spite of the foregoing statement, to be neglected by health and social agencies.

4. The death rate for Negro males is excessively high.

5. The death rate for all Negroes seems unreasonably higher than the death rate for the white race.

6. Certain groups in both races need special attention; for example, young females; old men; single, wichowed and divorced people.

7. Provision for the care of the transient tuberculous is lacking.

8. The percentage of the tuberculous aying in a sanatorium is higher locally than in the country as a whole.

9. The number of days' care per patient and the total cost per patient is higher at the local sanatorium than at the average public sanatorium. 
10. A high number of tuberculosis deaths occurs at the Central state Hospital.

11. In spite of much effort in the field of health education there is ignorance and indifference toward the local problems of tuberculosis on the part of many of those in position to help solve tine problems. 12. There is little general interest in the improvement of housing conditions.

13. There is general opposition toward permitting relief grants to meet the minimum ade uate standard of living.

All of these problems may be Grouped under three headings as foliows: Problems of Case-finding, numbers $1,2,3,4,5$ and 0 ; Problems of Adrinistration, numbers $7,8,9$ and 10 ; Problems of Publicity, numbers 11 , 12 and 13. 
VII. Suggestione for liore Effective Control of Tuberculosis 


\section{Suggestions for Lore Effective Control of Tuberculosis}

In subitting the following suggestions for more effective

control of tuberculosis in Lou sville and Jefferson County it is realized that the writer speaks somewhat as an outsider, perhaps not fully aware of all the obstacles in the way of putting the suggestions into effect. It is believed, however, that ali of them are practical and that all of theis are in successful operation in some locality, althougin not all in any one place.

Taking up first the suggestions to meet the problems of casefinding, we would point out that the evidence of all the statistics presented in the study under the headings of Race, sex, ige, warital Condition, cccupation and Community Agencies emphatically indicated the male Negro as the factor contributing most adversely to the local tuberculosis death rate; more specifically the unnarried male Negro flom 15 to 65 years of age and most specifically to those within the age froup 45 to 65 years. If the aeath rate for its male Negroes could te materialid reciuced Louisvilie woula imnediately gain in its tuberculosis status among other cities. Since it is probable that the low rate for Negro females in the city and county is due in large part to the active health eeucation and casefinding program carried on by Negro nurses and social workers in the homes of their patients and clients, and since tuberculosis takes its chief toll from the unmarried male Negro it is obvious that a male Negro health worker is needed to search out suspicious tuberculous cases in the haunts where they are most likely to be found. During the period of this study no rale liegroes except doctors were employed by health agencies for unti-tuberculosis work. 
A responsible person with the necessary wixture of qualities, including those of teacher, preacher and nan-about-town welcome in pool-rooms, saloons and gambling joints, wight be dificult to locate, but is probably more prevalent anong the Negro than the white race. In any event a good male liegro health worker is needed if unmarried male Negro tuberculous cases are to be found, brought into clinics and hospitalized. Until these cases are brought under care Louisville's outstanding tuberculosis proklem will not te met.

The next most important groups to work with are white men and women from 25 to 45 years of age. They provide more deaths than any other group, $25 \%$ of the total deaths; but they are especialiy important because every death in this age group represents the loss of actual or potential heads of families, persons of an age to make the highest social and economic contribution to the comunity. hen they are ill over a long period of time and when they die, the communty in approxirately four cases out of five rust support them and often their families. It is believed by medical authorities that most original cases of tubercular infection occur in young children and that the disease, quiescent until later in life, is usually traceakle to contact as a child with sone tuberculous adult. This fact makes tuberculosis doubly dangerous when it is active in the parents of young children, people who are usualiy in the 25 to 45 year age group. It is therefore both economicaliy sound and good health procedure to reduce the amount of tuberculosis among these people. The great majority of young adults in Louisville and Jefferson County who are suspicious tuberculous cases kelong to the midile and lower 
income class. While they are still in the early stages of the disease it is difficult to persuade them to go to a doctor or a clinic for a physical examination. They are naturally resistant toward losing a day's pay because of an indisposition which does not seem to them serious. Clinic attendance must be made easy for them. There should be mor $\theta$ frequent evening tuberculosis cinics for both Negroes and whites, and these clinics should be held every few months in outlying neighborhoods so that people can attend without much loss of time or money in travel. Before tuterculosis can be eliminated the cure must go to the people. Apprehensive people gladly seize upon little excuses to avoid putting their fears to the test.

Ith tuberculosis the highest cause of death anong young women of both races there should be a more intensive effort to reach them where they are. The present program of the Tuberculosis Association in giving free physical examinations in incustrial plants shoula be extended Either by them or by an official agency to include stores, office kuilciings and factories where many young women are employed. This is an expensive method of case-finding, but it is valuable not only in the field of tukerculosis, but as a means of naking young woren at work wore aware of all their health assets and defects. Attendance at the clinic for domestic servants shoula be encouraged und the value of a good health report from it should be enhanced.

The map on page 19 shoving the areas of the city where nost tuberculosis is found and the information on page 37 showing which of these areas are least known bj health and social agencies, should be 
studied and more intensive visiting directed toward those neighborhoods in the interest of case-fincing in the productive field of contacts. Although the actual rumber of persons 45 jears of Ege and over who die from tuterculosis was not so high as in the imediateiy Lower age group, the deatri rates in these iater years was higher tran uny were else. Woreover, arong these older people there is apt to be a carelessness about their own habits und a callousnesi to the danger of infecting others with their aisease, many instances of childhood infection have occurred through the presence of a tuberculous granaparent in the housenold. Consideration of tuterculosis as a fanily problem, not as a matter of concern to the patient alone, would seeis to be the way to Inet the situation when the older patient is a member of a family. Visits to the cheaper type of hotel, men's lodging house, nursing hone and to the Transient Bureau in the interest of general heaith inspection would reveal nany unreported cases of tuberculcsis anong widule aged and older residents.

The problem of case-finding is closely related to and often cependent upon the administrative policies of the agencies working in the field of tuberculosis. Changes in these policies are more aifficult to achieve than minor changes in procedures, but they have more far reaching results.

The host freguent criticsm of the tuberculosis prosram of Louisville and Jefferson County, made by visiting specialists in the health field, is that too much time anci attention are given to institutional care of the chronic tuberculous patient and not enough to finding and hospitalizing the early remeaial case. The high proportion of deaths at the local 
senatorium and the liigh nuraber of day's care and consecuent cost per patient, as compared with similar figures for other public sanatoria, substantiate this criticisn. Jiscussion with the medical authorities in charge of admissions to the institution has brought out the fact that the present proceaure is a definite policy und that there is no imsediate intention to change that policy.

In line vith this policy is the type of nursing personnel eruployed by the clinic. These nurses are responsible for all the field vork in case-finding as well as for bedside care of the patients in the home and for assistance to the physician during the clinics. They are good hospital nurses, well trained by the clinic medical director in clinic adwinistration and in care of the tuberculous patient, whether anbulatory or confined to bed. They have had no training in public health nursing, where emphasis is placeá on comunity ana family health as vell as on the immediate patient; they lack supervised training in health teaching, cooperative work with other health and social agencies, basic nutritional eaucation and modern psychologic and psychiatric information. There is a definite clinic policy not to employ trained public health nurses.

The remedy suggested for this situation is drastic and probably impossible to put into immediate effect. There would seem to be no doubt, however, that the tuberculosis death rate in the cominnity would be lower if the Waverley Sanatorium and clinics could be amalgamated with the already proposed joint City-County Health Department. As a branch of City rospital the sanatoriun would be more readily accessible to tuberculous patients now frequently held for long intervals at the hospital or in their 
homes, but the greatest advantage in the change woulo be in the more agoressive case-finding policy resulting from the larger number of. better trained public health nurses, among them several Negro nurses, who would uncoubtedly bring more suspicious cases to the tuberculosis clinics. Nurses who work constantly in child health conferences and in the public and parochial schools have an exceptional opportunity to meet and to discuss health problems with all types of families; their technique has been developed in the stimulation of families and individuals to assume responsibility for the health of themselves and of others. With the adition of tuberculosis to the official public health program the comunity would receive a more complete and progressive service in this field.

If this radical administrative change could be effected the bedside nursing care of tuberculous patients confined to bed in their own homes would have to be turned over to the Visiting Nurse Association. The Health liepartment should probally pay the Association for this care, which is at present being paid for out of tax funds. An equally valuable and equaliy difficult administrative change would be the opening of a long needed chronic disease hospital for Louisville and Jefferson County, also as a branch of the present City hospital, to wich could be transferred many of the chronic tuberculous cases now occupying beds at vaverley Sanatorium. This sanatorium is vell equpped medicaliy and sur-

1. The recent administrative change whereby this recomendation has already $b \in \in \mathfrak{n}$ put into $\in$ ffect should soon begin to show the beneficial results here outlined. 
Eically to care for serious, acute stages of tuberculosis. Tile more expensive service required for these cases is not needed for cld chronic cases; adecuate. care for them could be provided in an institution whose cost would be at least one doliar per aay per patient less than the suatorium cost. The sunatoriun varas should not be clogged vith chronic cases for Whom little but custodial care until deuth is required.

lore dynamic case-finding should result in the discovery of nore early cases of tuberculosis and these should be able to receive immediate hospitalization if it is medicalıy recomended. Fxperience in other places has shown that many such patients can be returned to the community with their disease quiescent in a comparatively short time. Two valuable objectives are thus achieved - the acute ease is renoved from the possibility of infecting others, and a (usually) young person is returned to resume his place in the comminity with the knowledge of how to protect his own and other peoples' health, before extensive darage has occurred. This sugbestion calls for a more rapici turnover in patients at Waverley Sanatorium and because of the greater amount of attention needed by such acute cases might result in a slightly higher per dien cost per patient. However, the reduction in ultimate cost of tuberculosis to the commity and the imisediate reduction in cost to both relief and health agencies (incident to the early removal of the patient to the hospital) should compensate for the slight aditional expense at the sanatoriun. It is believed such a eduction may reasonably be made from the instance previously cited, of the concurrent decrease in number of Negro male tuberculous patients at the sanatorium with a considerable increase in the 
number of Negro male patients dying in their own homes and known to relief agencies.

i change in administrative policy affecting other than the public agencies is concerned with the nurses' training schools in private hospitals. About one-fifth of all deaths from tuberculosis in the area studied occur in families apparently able to provide medical and nursing care for themselves either at home or in hospitals. Lust of the nurses giving such care are graduates of local private hospital training schocls, yet none of these hospitals admit enough patients with recognized communicable disease to provide adequate training in this subject for their student nurses. It is therefore sugested that an affiliation in comunicable disease nursing be set up at waverley Sanatorium where students from private hospital training schools could be taught aseptic technique in any medical condition. These nurses would become wcouainted with the symptoms of tuberculosis and with desireable procedures for its control. Their own future teaching would reach families of an economic level selaom visited by nurses of the official alealth Department or of the Visiting Nurse Association.

A final suggestion in the field of administrative policy relates to the care of the tukerculous transient. Steps should be taken to make mandatory on some state office the financial support of these dangerous persons. It is now legally the responsibility of the county of which the patient is a resident, but the ability of many of these counties to meet their financial obligations is nihil. So long as there are no free beds for tuterculous patients in other parts of the state it is inevitable 
that some of them will come to Louisville and Jefferson County seeking hospitalization. Here they are a danger to many people since trey cannot legally be admitted to local institutions. It vill probably require action at the state level to solve this deadock, but the need clearly points to some such solution.

For transients from other states found to have tuberculosis temporary free care should probably be provided in a local institution, in the interest of safeguarding local citizens, until arrangements can be made to return the sick migrant to his own state. other states are known to perform a like service for Kentucky.

A note should be made in this section on administrative problems regarding tuberculosis at Central state Hospital. No recomnendation is necessary since it is understood that the new management there has recently segregated ano given special attention to the tuberculous patients, so that they are no longer a source of infection to others.

Changes in administrative policy and in case-finding depend to a large extent on placing before those in authority or with influence in the comrunity, information of the kind that convinces then the changes are possible and desireable. Since different people are notivated by different impulses the content of the information and the method of presenting it will vary, but the following suggestions are offered as meting to some extent the needs in this field.

The necessary basis for the indicated approach would be the continuous collection and analysis of local tuberculosis statistics, as 
compared with similar data from other places. At the present time the monthly and annual reports of waverley sanatorium and clinics are given practically no publicity. Neither they nor the annual reports of the Tuberculosis Association present information as to the fundarental criteria relating to tuberculosis. Although much general information about tuberculosis is presented to the public during Early Diagnosis We Negro Health veek there is little focus of attention on local conditions. Wile shot-gun scattering of health education material has its place there are certain educated and sophisticated groups who are bored by it. They are often composed of educated people who, it is believed, would respond to a documented and indivicualized appeal for their assistance in changing certain conditions where Louisville was admittedily below standard. Included among these groups should be the Board of iuberculosis lospital and the Board of the Tuberculosis Association. At the time When financial appeals for the support of tubercuiosis institutions and agencies are presented to the City Cuncil, the County Comissioners and the Comanity chest a brief report should be made on conditions and trends in tuberculosis, both locally and nationally. only with such a background of achievement and need can rational appropriations be made. Since not all of the medical profession are aware of the place of the tuberculosis sanatorium and clinics in the cominity it anight be well for one of the visiting tuberculosis specialists who address the local County liedical Society annually, to focus his talk specifically on local conditions. Louisville evinces a tolerance, not entirely confined to its Iay citizens, toward the danger of tuberculosis. 
Another group in constant contact with tuberculous families is composed of social workers. If their training could inciude more $\in \mathrm{m}-$ phasis on the far-reaching social implications of tuberculosis the practicing social worker would probably be more alert to symptoms of early disease and quicker to see that clients obtained medical care and aceTuate relief to provide for hygienic living.

The Eeneral population is certainly more nutrition conscious than it was a few years ago, but if we are to prevent and to overcorae chilarood tuberculosis in Louisville and Jefferson County, it will be necessary to inpress this public with the netd for nutritious food auong the groups who depend on the public for their food allowance.

Publicity is also needed to bring before the public the neta for official housing inspection, now a missing item in the local health program. although Louisvilie has very few tenements of the type found in large eastern cities it does have numerous old one-family houses now occupied by several families. Toilet and water facilities are inadequate for the present occupancy, plumbing is dilapiaated and unsafe, rooms are overcrowded with people and halls are blocked with the apparatus of crowded Living. it present the only cure for bad housing conditions being presented to the public is the expensive method of slum clearance and erection of new houses. There is another remely for bac housing which, while only effecting a partial cure, is much less costly and wore universaliy applicabie. Periodic inspection of tenements, rooming and lodeing houses by the local tealth jepartment would make not only for the correction of insanitary conoitions and bad housekeeping, but could also be the ratans 
for revealing to an alert inspector wany unreported cases of comunicable distase. A law or city oráinance peruitting such inspection shculu be passed. The inspection service, like the similar service to dairies, could be made to pay for itself by a systeli of licensing.

Briefly sumarized the sugestions for control of tulerculosis in Louisvilie anci jefferson County are as follows:

1. Limployment of a vell-trainea nale negro heilth vorker.

- Frovision of adidional evening tuberculosis clinics for both white and Negro patients and suspected cases.

3. Frovision of tuberculosis clinics at refular intervals in outlying parts of the city and county

4. Provision of free health examinations for young voren in inciustries, offices and stores.

5. ixpansion of the services of the clinic for comestic servants.

6. Intensive healtr eaucation in geographic areas where considerable tuberculosis is known to exist.

7. Amalganation of waverley Sanatorium and clinics with the joint City-County Jealth Department.

8. Assignent to all nurses in this enlarged official health agency of responsibility for health education in the field of tuberculosis and for nursing service in tuberculosis clinics.

9. Assignment of responsibility for bedside nursing of tuker- 
culous patients in their own homes to the Visiting Nurse Ascociation, with payment for such service by the lealth Department.

10. Removal of chronic tuberculcus patients from laverley Sanatorium to special wards in a new Chronic lisease Hospital.

11. Establishment in the curriculum of all nurses' training schools in private hospitals of a required course in nursing care of tuberculosis as a typical comunicable disease.

12. Assignuent to some department of the State government of the financial responsibility for care of tuberculous transients who are citizens of the state.

13. Assignment to the local Health Department of the responsibility for teuporary care of tuberculous transients from other states.

14. Provision for collection, analysis and appropriate publicity of local tuberculosis statistics.

15. Presentation of these statistics and other material relating to local tuberculosis problems to various groups of citizens responsible for the health of the comunity.

16. Institution of legal and financial measures for sanitary inspection of tenements and other types of mitiple divellings. 
VIII. Conclusion 


\section{Conclusion}

In the introauction to this report several questions were posed to which answers can now be given.

Is tuberculosis no longer an important problem for Louisville and Jefferson County? With an average of 24.7 deaths of local residents each year from tuberculosis and with $2 \%$ of the total population affected as patients or as contacts, tuberculosis still presents a serious realth problen to the city and county.

Do Louisville and Jefferson County compare favorably in tuberculosis rates with other parts of the country? Although the local rates for a few age groups among whites and Negroes are better than the rates for comparable national groups, the local general tuberculosis death rate is considerably higher than the national death rate; Louisville has thiro from the highest death rate anong the fourteen cities of its population class.

What is the financial cost of tuberculosis to the com unity? Local agencies dealing directly and exclusively with tuberculosis spent during $1934-1938$ an annual average of $\$ 429,146.00$ or $\$ 1.21$ for each man, woman and child in Louisville and Tefferson County. The average patient hospitalized at Vaverley Sanatorium cost the comunity $\$ 762$. The adcitional cost of tuberculous patients in other public institutions, and the support and supervision of the families of the tuberculous ( $80 \%$ of whom are visited by some social or heulth agency) cannot be accurately estimated, but it must approximate the known figure stated above. Together they result in a tremendous drain of finances now being spent on a disease 
which could be practically eradicated by un intensive rational attack. Is the expenditure of tax money and private contributions resulting in decreased inciatence of tuberculosis? Local tuberculosis death rates are decreasing, but not so rapidly as in some other communities which are spending lesser amounts of noney nore intelidgently. Is Louisville's complacency regarding its tuberculosis problem justified? No comiunity should be sutisfied with spending more money on its tuberculosis program than other comunities spend while getting less effective results. where Louisville has waged its anti-tuberculosis campaign intensively and intelligently the results have merited satisfaction, but numerous other groups and areas show the result of neglect.

Repeated generalizations about any subject tend to dull interest in it. Tuberculosis was the first disease to be presented to the public as a subject of social responsibility; recurrent years of the campaign, however, have brought an inevitable apathy both to campaigners and campaigned. The objective of this report has been to dig beneath the routine, wellworn surface truths concerning tuberculosis and to bring up some sharp, pointed nuggets of local fact with which to prick local audiences to a greater degree of interest in and responsibility for the eradication of tuberculosis from Louisville and Jefferson County. 
Bitliography 


\section{BIBLIOGRAPHY}

\section{Books}

liscock, Ira V.

Communty Health organization

New York, The Comonwealth Fund, 1939

Hall, L.F.

Public lealth Statistics

Ann Arbor, Brumfield and Brumfield, 1936

Whitney, Jessamine,

Facts and Figures About Tuberculosis

New York, National zuberculosis Association, 1931

Witney, Jessamine

New and Supplementary Facts and Figures About Tuberculosis

New York, National Tuberculosis Association, 1935

\section{Reports}

Bureau of the census

U.S. Census for 1930

ashington, Government printing office, 1931

Buck, Garl

Survey and Appraisal of the fealth activities and lieeds of Louisville Louisville, Listributed by the Louisville Lecilth Council, 1936

Lrolet, C.J.

Tuberculosis hortality in Forty-six Large cities of the united states During the year 1933

Ne: York, New York Puberculosis and Fealth Association, 1959

Louisville Tuberculosis Association, Annual Reports, 1934-1930

Boaro of Tuberculosis iospital, annual heports, (unputlished), 1934-1938

1.unicipal fousing Corasision, Ieports, (unpublished), 1936-19:0 


\section{Periodicals}

Council on redical Education and Fospitals of the American ladical Association Survey of Tuberculosis hospitals and Sanatcriuns in the United states

Journal of the American lecical Association, Dec. 7,1935, p. 1855

Drolet, C.I.

spiderilology of iuberculosis

Journal of Preventive liedicine, larch, 1930

\section{other laterial}

Copies of Death Certificates of residents of Louisville and Iefferson County whose Cause of Death was reported as Tuberculosis

Verbal comments and correspondence concerning sections II and III of the thesis, from lr. Oscar 0 . Miller, hedical Director of waverley Clinics and Field work, anc from Dr. Benjamin L. Brock, ledical Director of laverley Sanatcrium 